\title{
Metabotropic glutamate receptor 5 knockout reduces cognitive impairment and pathogenesis in a mouse model of Alzheimer's disease
}

\author{
Alison Hamilton, Jessica L Esseltine, Rebecca A DeVries, Sean P Cregan and Stephen S G Ferguson*
}

\begin{abstract}
Background: Alzheimer's disease (AD) pathology occurs in part as the result of excessive production of $\beta$-amyloid (A $\beta$ ). Metabotropic glutamate receptor 5 (mGluR5) is now considered a receptor for $A \beta$ and consequently contributes to pathogenic $A \beta$ signaling in $A D$.

Results: Genetic deletion of mGluR5 rescues the spatial learning deficits observed in APPswe/PS1 $\triangle E 9$ AD mice. Moreover, both $A \beta$ oligomer formation and A $\beta$ plaque number are reduced in APPswe/PS1 $\triangle E 9$ mice lacking mGluR5 expression. In addition to the observed increase in A $\beta$ oligomers and plaques in APPswe/PS1 $\triangle E 9$ mice, we found that both mTOR phosphorylation and fragile $X$ mental retardation protein (FMRP) expression were increased in these mice. Genetic deletion of mGluR5 reduced A oligomers, plaques, mTOR phosphorylation and FMRP expression in APPswe/PS1 $1 \mathrm{E} 9$ mice.

Conclusions: Thus, we propose that $A \beta$ activation of mGluR5 appears to initiate a positive feedback loop resulting in increased $A \beta$ formation and AD pathology in APPswe/PS1 $\triangle E 9$ mice via mechanism that is regulated by FMRP.
\end{abstract}

Keywords: Alzheimer's disease, APPswe/PS1 EE9, mGluR5, Beta amyloid, FMRP, Learning and memory

\section{Introduction}

Alzheimer's disease $(\mathrm{AD})$ is the most prevalent neurodegenerative illness in older adults and has a characteristic neuropathology that includes plaques comprised of $\beta$ amyloid $(A \beta)$ and tangles of hyperphosphorylated tau $[1,2]$. A $\beta 42$ is formed by the sequential proteolytic cleavage of the amyloid precursor protein (APP), by $\beta$ - and $\gamma$-secretases, via what is referred to as the amyloidogenic pathway and are commonly found as soluble oligomers and fibrillar plaques [3]. A considerable body of evidence suggests that soluble $A \beta$ oligomers are the predominant neurotoxic species of $A \beta$, with the $A \beta 42$ fragment being found to be particularly potent $[4,5]$. A $\beta 42$ oligomers exert their toxic effects by binding to neuronal synapses, causing disruption to normal synaptic signaling, which often leads to neuronal death [6,7]. However, the

\footnotetext{
* Correspondence: ferguson@robarts.ca

The J. Allyn Taylor Centre for Cell Biology, Robarts Research Institute, The University of Western Ontario, 100 Perth Dr, London, Ontario N6A 5 K8, Canada
}

precise receptors to which $A \beta 42$ binds remain very controversial.

Glutamate is the primary excitatory neurotransmitter in the brain and activates both ionotropic glutamate receptors and G protein-coupled metabotropic glutamate receptors (mGluRs) [8]. Alterations in normal mGluR5 signaling is associated with the autism spectrum disorder, fragile X syndrome, and a number of neurodegenerative diseases that include: Huntington's disease, Parkinson's disease and $\mathrm{AD}$ [9-17]. mGluR5 couples to the heterotrimeric $G$ protein $G \alpha_{\mathrm{q} / 11}$, which activates phospholipase $\mathrm{C}$ resulting in increased inositol-1,4,5-triphosphate formation and the release of $\mathrm{Ca}^{2+}$ from intracellular stores $[3,12]$. Recently, it has been demonstrated that mGluR5 also serves as the receptor for both cellular prion protein $\left(\operatorname{Pr} \mathrm{P}^{\mathrm{c}}\right)$ and $\mathrm{A} \beta 42$, which activate mGluR5 to release $\mathrm{Ca}^{2+}$ from intracellular stores [17-20].

It is now well recognized that mGluR5 regulates the activity of the fragile $\mathrm{X}$ mental retardation protein (FMRP), a RNA binding protein that functions to repress protein synthesis at synapses [21-25]. The activation of 
mGluR5 results in FMRP-dependent increases in both APP and FMRP expression [16,26]. This increase in APP expression results in the augmented secretion of both toxic A 342 oligomers and the non-toxic soluble APP $(\mathrm{sAPP} \alpha)$ fragment $[16,24]$. Thus, although the precise mechanism remains unclear, this data suggests that, in addition to an established role in fragile $\mathrm{X}$ syndrome, mGluR5 and FMRP likely contribute directly to AD pathogenesis [16,27].

In the present study, we assess the role for mGluR5 in $\mathrm{AD}$ pathogenesis by crossing the APPswe/PS1 $\triangle \mathrm{E} 9$ double transgenic mouse model of AD with mGluR5 null mice. We find that the genetic deletion of mGluR5 reverses the spatial memory deficits observed in APPswe/PS1 $\triangle \mathrm{E} 9$ mice. FMRP protein expression is also increased APPswe/PS1 $\triangle \mathrm{E} 9$ mice and following the genetic deletion of mGluR5 FMRP expression is reduced to wild-type levels and results in the significant decrease of aggregated $\beta$-amyloid levels and $\beta$-amyloid plaque number in APPswe/PS1 $\Delta \mathrm{E} 9$ mice. These studies provide evidence for a central role of mGluR5 in AD pathogenic mechanisms that are associated with increased $A \beta$.

\section{Results}

\section{Genetic deletion of mGluR5 rescues spatial memory} deficits in APPswe/PS1 $\triangle E 9$ mice

Given the potential role for mGluR5 as a receptor for $A \beta$ [17-20], we crossed mGluR5 knockout mice with APPswe/ $\mathrm{PS} 1 \triangle \mathrm{E} 9$ mice. The double transgenic APPswe/PS1 $\Delta \mathrm{E} 9$ mice were previously found to exhibit impaired cognitive function as early as 7 months of age [28-30]. Therefore, our initial studies tested whether the genetic deletion of mGluR5 improved spatial memory deficits in APPswe/ PS1 $\triangle \mathrm{E} 9$ mice at both nine and twelve months of age in the Morris Water Maze test. Mice were exposed to the maze for sixteen $90 \mathrm{~s}$ trials over 4 days during the acquisition phase ( 4 trials per day), followed by a $60 \mathrm{~s}$ probe trial on day 5 . The swimming ability for all four mouse genotypes was consistent and indistinguishable at both nine and twelve months of age (Figure 1A and B). However, repeated measures analysis of variance indicated that spatial learning of 9 month old mice (Figure $1 \mathrm{C}$ and E), as measured by either the escape latency or swim path length, varied as a function of the genotype, $F(3,41)=4.83$, and 11.20 , p's $<0.01$, respectively. Precisely the same profile was apparent in mice at 12 months of age (Figure 1D and F). Follow-up Bonferonni corrected t tests confirmed that performance of APPswe/PS1 $\triangle \mathrm{E} 9$ mice was significantly impaired when compared to wild-type and $\mathrm{mGluR5}^{-/-}$mice. However, the genetic deletion of mGluR5 rescued the spatial learning deficit in APPswe/PS1 $\triangle \mathrm{E} 9$ mice at both ages. The genotype differences were consistent and the interaction between Strain and Days did not reach statistical significance.
During the probe trial on day 5 , in which the platform was removed, the genotypes varied appreciably with respect to the time spent in the target quadrant, $F(3,41)=$ 20.62 and 21.66, p 's $<0.001$ for mice tested at 9 and 12 months respectively. The follow-up tests confirmed that APPswe/PS1 $\triangle \mathrm{E} 9$ mice spent less time in the target quadrant relative to all other genotypes at either nine or twelve months of age, but that the loss of mGluR5 expression improved APPswe/PS1 $\triangle \mathrm{E} 9$ mouse behaviour (Figure $1 \mathrm{G}$ and $\mathrm{H}$ ). The time that the mice spent in each quadrant of the pool is shown in Additional file 1: Figure S1. Thus, our observation that the genetic deletion of mGluR5 resulted in significantly improved spatial temporal memory in APPswe/PS1 $\triangle \mathrm{E} 9$ mice was consistent with a recent report that pharmacological blockade of mGluR5 improved behavioural deficits in APPswe/PS1 $\triangle \mathrm{E} 9$ mice [17].

\section{Effect of APPswe/PS1 $1 \mathrm{E} 9$ mutation on the locomotor, anxiety and exploratory behavioural phenotypes of mGluR5 $^{-1-}$ mice}

We previously showed that $\mathrm{mGluR}^{-/-}$mice exhibit increased locomotor activity that is reversed in the Q111 knock-in mutant huntingtin genetic background [12]. Moreover, APPswe/PS1 $\triangle \mathrm{E} 9$ mice were previously shown to exhibit impaired exploratory behavior $[28,29]$. Therefore, we wanted to ascertain that double transgenic expression of APPswe and PS1 $\triangle \mathrm{E} 9$ does not alter changes in the locomotor (distance traveled), anxiety (centre time) and exploratory (number of rearing events) behaviours induced by mGluR5 deletion in twelve month old wild-type and APPswe/PS1 $\triangle \mathrm{E} 9$ mice lacking mGluR5 expression over a $2 \mathrm{~h}$ period in an open field arena. We found no differences in the locomotor, centre time and exploratory behaviours of APPswe/PS1 $\triangle \mathrm{E} 9$ mice when compared to wild type controls (Figure 2A-C). However, the genetic deletion of mGluR5 resulted in locomotor hyperactivity, reduced centre time in the open field, as well as increased exploratory behaviours in both APPswe/PS1 $\triangle \mathrm{E} 9$ mice and wild type controls (Figure 2A-C). However, we did not find a statistically significant increase in anxiety behaviour in mGluR5 knockout mice in the elevated plus maze (Figure 2D and E). Thus, double transgenic expression of APPswe and PS1 $1 \mathrm{E} 9$ does not alter the changes in locomotor, anxiety and exploratory behaviour that occur as the consequence of mGluR 5 deletion.

\section{Genetic deletion of mGluR5 reduces A $\beta$ in APPswe/PS1 1 E9 mice}

Given that mGluR5 deletion improved cognition, we sought to examine the effect on $A \beta$ production and deposition. The deposition of $\mathrm{A} \beta$ in APPswe/PS1 $\triangle \mathrm{E} 9$ mice occurs as early as 3 months of age [29-31]. Therefore, to assess the role of mGluR5 on A $\beta$ oligomer load, whole brains from 12 month old mice were analyzed for $A \beta$ oligomers using a sandwich 

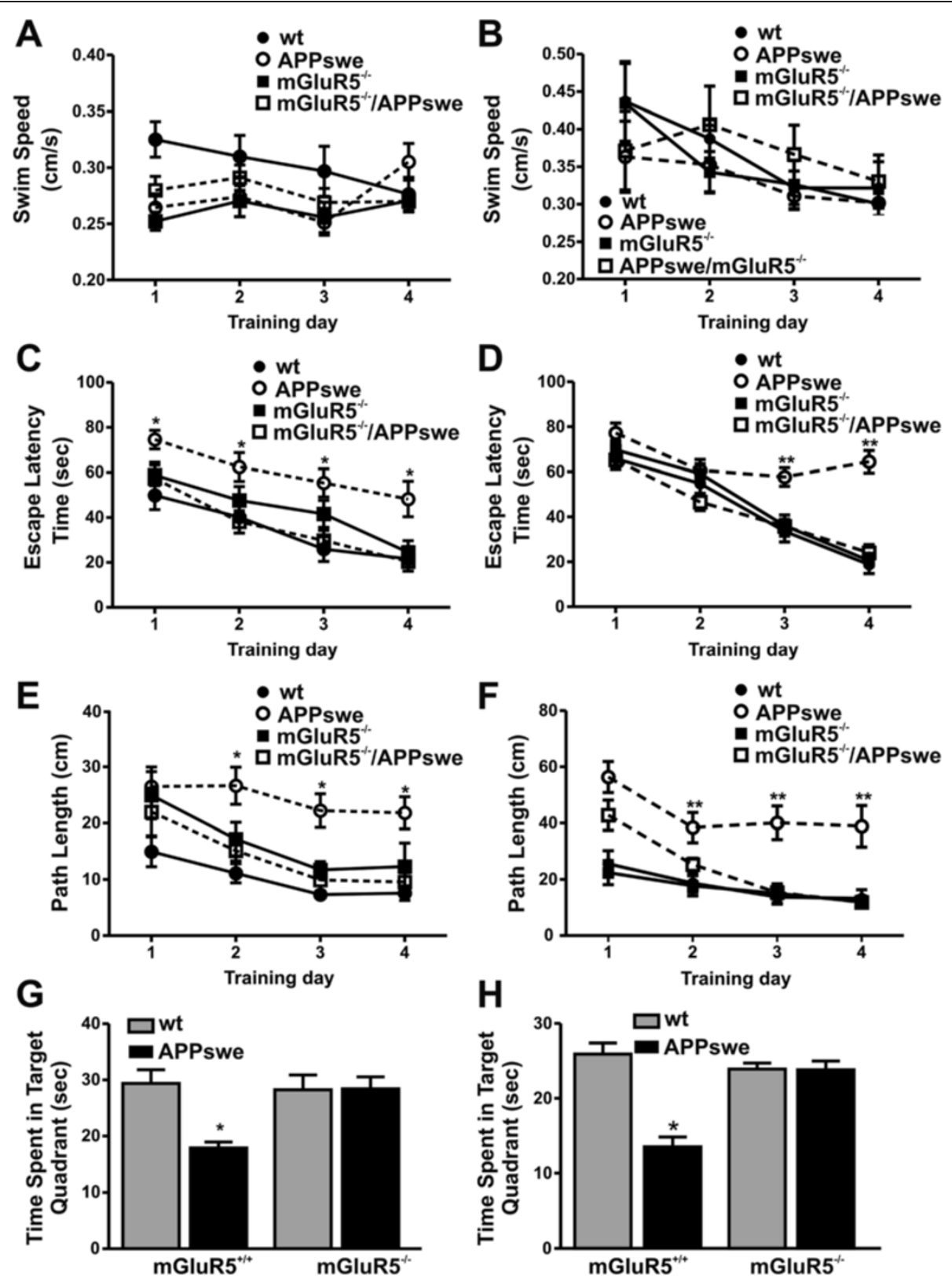

Figure 1 Genetic deletion of mGluR5 rescues spatial memory deficits in APPswe/PS1 1 E9 mice at 9 and 12 months of age. Shown are the swim speeds at (A) 9 and (B) 12 months of age, escape latencies, at (C) 9 and (D) 12 months of age, and path lengths (E) at 9 and (F) 12 months of age for wild-type (wt) ( $n=16)$, APPswe/PS $\triangle$ E9 (APPswe) $(n=11)$, mGluR5-/- $(n=14)$, and APPswe/mGluR5-/- $(n=14)$ mice recorded during the acquisition phase in the Morris Water Maze test for spatial learning. Shown is the time that wt, APPswe, mGluR5-/-, and APPswe/ mGluR5-/- mice spent in the target quadrant during the probe trial at (G) 9 and $\mathbf{( H )} 12$ months of age. Data represent the mean \pm SEM. Statistically significant * $(p<0.01)$ and ${ }^{* *}(p<0.001)$ differences between mice groups when compared to wild-type mice. Statistical significance was assessed by repeated measures ANOVA.

ELISA assay. We found a $3.7 \pm 0.5$ fold increase in $A \beta$ oligomers in APPswe/PS1 $\triangle \mathrm{E} 9$ mice when compared to wild-type controls, this increase in $\mathrm{A} \beta$ oligomers in APPswe/PS1 $\triangle \mathrm{E} 9$ mice was reduced to $1.2 \pm 0.2$ fold following the genetic deletion of mGluR5 (Figure 3A). This represented a $41 \pm 6 \%$ reduction in $\mathrm{A} \beta$ oligomers in $\mathrm{APPswe} / \mathrm{PS} 1 \triangle \mathrm{E} 9$ mice lacking mGluR5 expression when compared to APPswe/PS1 $\triangle \mathrm{E} 9$ mice that express mGluR5. We also examined whether the number of $A \beta$ plaques were altered in APPswe/PS1 $\triangle E 9$ mice lacking mGluR5 to rule out the possibility that $A \beta$ oligomers were simply being converted more efficiently to plaques to reduce cognitive decline. When quantified we found that $A \beta$ plaque number was also reduced in the cortex and hippocampus of coronal brain slices, with the $A \beta$ plaque 


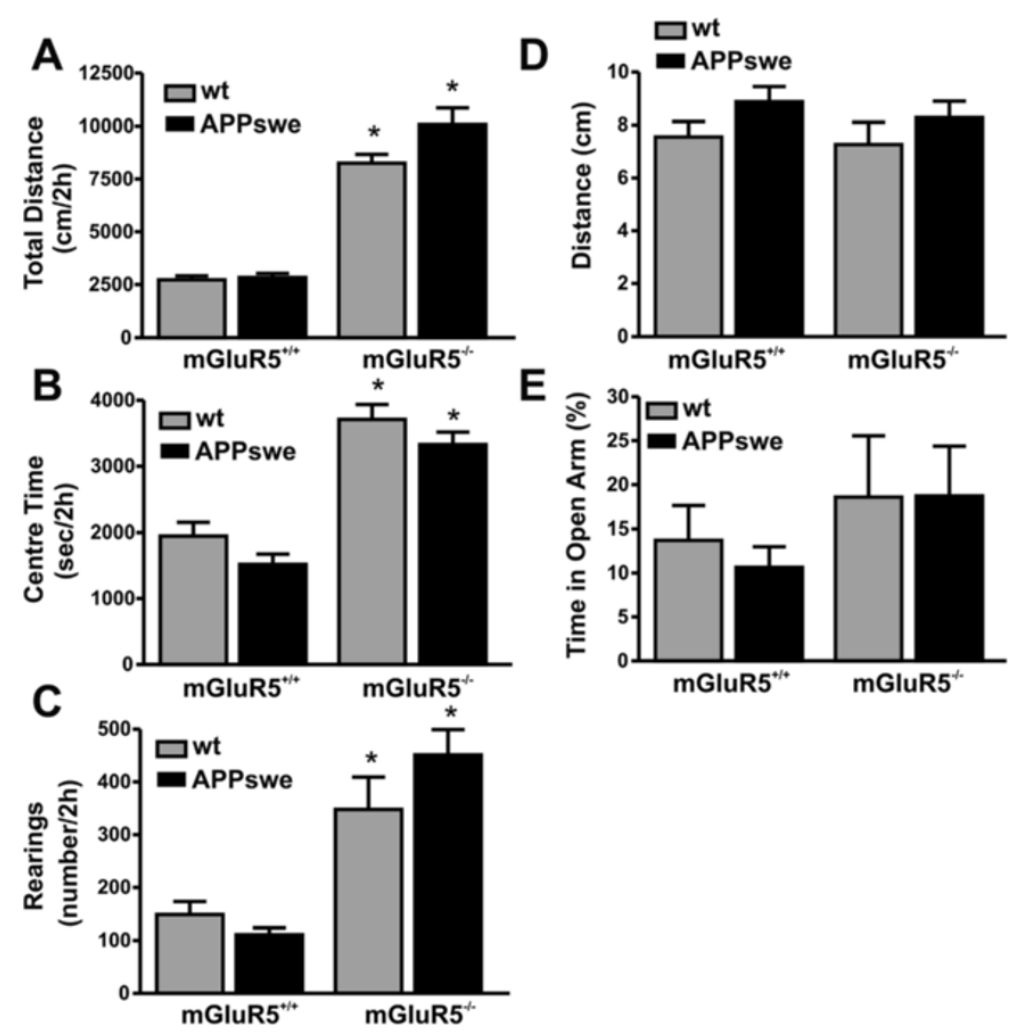

Figure 2 Genetic deletion of mGluR5 increases locomotor, anxiety and explorative behaviours in wild-type and APPswe/PS1 $\Delta$ E9 mice at 12 months of age. Graphs show (A) the total distance traveled, (B) the time spent in the centre quadrant of the open field and (C) number of rearings for wild-type (wt) and APPswe/PS1 $\triangle E$ E9 (APPswe) mice on either mGluR5+/+ or mGluR5-/- genetic backgrounds. (D) Show is the total distance traveled in the elevated plus maze. (E) Shown is the percentage of time spent in the open arm of the elevated plus maze. The number of animals tested: $n=16$ for wt, $n=11$ APPswe, $n=14$ for mGluR5-/- and $n=14$ for APPswe/mGluR5-/ - mice. Data represent the mean \pm SEM. The * indicates statistically significant $(p<0.05)$ differences between mice groups as compared with wild-type mice.

load reduced by $34 \%$ and $40 \%$ in cortex and hippocampus, respectively (Figure 3B-D). Because APP was transgenically (ectopically) overexpressed in APPswe/PS1 $\triangle \mathrm{E} 9$ mice, we tested whether the reduction of $A \beta$ following the genetic deletion of mGluR5 was associated with reduced APP expression in whole brain lysates derived from 12 month old wild type and APPswe/PS1 $\triangle E 9$ mice that either expressed or lacked mGluR5. We found that the genetic deletion of mGluR5 had no apparent effect on the transgenic APP expression in double transgenic APPswe/PS1 $\triangle \mathrm{E} 9$ mice (Figure 3E). Thus, the expression of mGluR5 appeared to influence the cleavage of APP towards an amyloidogenic pathway in the APPswe/PS1 $\triangle \mathrm{E} 9$ double transgenic mouse model, and mGluR5 deletion functions to reduce both $A \beta$ oligomer formation and plaque number in APPswe/PS1 $\triangle \mathrm{E} 9$ mice.

\section{mGluR5 cell surface expression and InsP signaling in APPswe/PS1 1 E9 mice}

$A \beta$ oligomers were previously reported to activate mGluR5 and promote mGluR5 clustering at synapses [18]. Therefore, we examined whether the cell surface expression of
mGluR5 was altered in APPswe/PS1 $\triangle \mathrm{E} 9$ mice at 12 months of age as compared to wild-type controls. Using coronal brain slices from 12 month old wild type and APPswe/ $\mathrm{PS} 1 \Delta \mathrm{E} 9$ mice, we determined total mGluR5 expression, as well as the plasma membrane expression for mGluR5 by performing a cell surface biotinylation assay [32]. We found that the cell surface expression of mGluR5 was increased by $4.4 \pm 0.7$ fold in APPswe/PS1 $\triangle \mathrm{E} 9$ mice when compared with wild-type mice, without a change in total cellular expression of mGluR5 (Figure 4A and B). No mGluR5 expression was observed in mGluR5-/- mouse lines. The observed increase in mGluR5 cell surface expression suggested the possibility that mGluR5-dependent cell signaling in APPswe/PS1 $\triangle \mathrm{E} 9$ was increased in vivo in response to either glutamate or soluble $A \beta$ oligomers. Therefore, we tested whether InsP formation in cross chopped (prisms) cortical brain slices derived from 12 month old wild-type and APPswe/PS1 $\triangle \mathrm{E} 9$ mice, that either express or lack mGluR5 expression was altered following treatment with the Group I mGluR agonist DHPG ( 5 or $50 \mu \mathrm{M}$ ). We found that despite increased mGluR5 cell surface expression in APPswe/ 

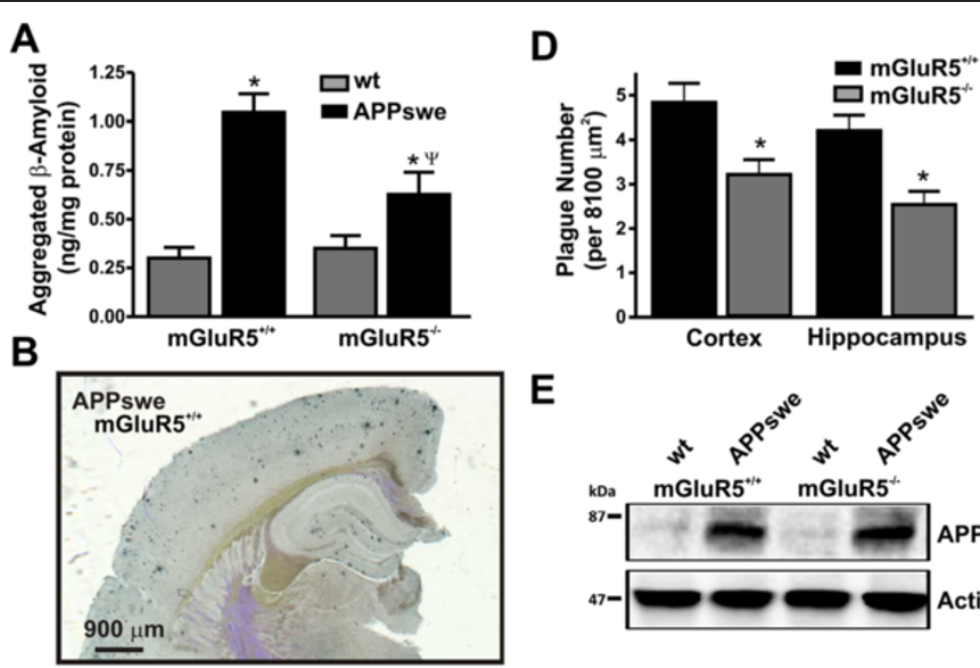

E

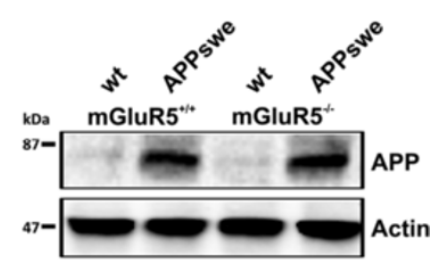

C
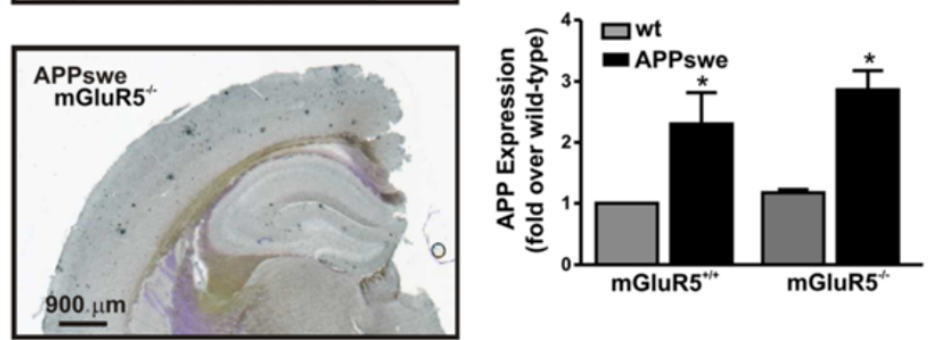

Figure $3 \mathrm{~A} \beta$ formation and plaque number is reduced in 12 month old APPswe/PS1 $\Delta$ E9 mice following the genetic deletion of mGluR5. Shown in (A) is the concentration of whole brain $\beta$ amyloid oligomer ( $\mathrm{ng} / \mathrm{mg}$ protein) concentrations in 12 month old wild-type (wt) and APPswe/PS1 1 E9 (APPswe) mice on either mGluR5+/+or mGluR5-/-genetic backgrounds. Data represents the mean \pm SEM of four independent experiments. The * indicates statistically significant $(p<0.05)$ differences between $\beta$ amyloid oligomer concentrations in APPswe/PS1 $\Delta$ E9 mouse brains as compared with mice that do not express APPswe/PS1 $\triangle E 9$. The ${ }^{*}$ indicates statistically significant differences between $\beta$ amyloid oligomer concentrations in APPswe mice that express mGluR5 as compared to APPswe mice that lack mGluR5 expression. Also shown are representative images of A $\beta$ plaques in the cortex and hippocampus of 12 month old coronal brain slices from (B) APPsweand (C) APPswe/mGluR5-/- mice. Scale bar is $900 \mu \mathrm{m}$. (D) The graph shows the number of plaques counted $8100 \mu \mathrm{m}^{2}$ regions of interests in the cortex and hippocampus in coronal brain slices from 12 month old APPswe and APPswe/mGluR5-/- mice. (E) Representative immunoblot and quantification of APP expression in wt and APPSwe mice either expressing or lacking mGluR5 expression. Data represents the mean \pm SEM of four independent experiments. The * indicates statistically significant $(p<0.05)$ differences between APPswe expressing mGluR5 as are compared with APPswe lacking mGluR5 expression.

$\mathrm{PS} 1 \Delta \mathrm{E} 9$ mice at 12 months, agonist-stimulated (DHPG) InsP formation was not significantly different between cortical prisms derived from either 12 month old wildtype or APPswe/PS1 $\mathrm{E} 9$ mice (Figure 4C). However, an increase in DHPG-stimulated InsP formation was observed in APPswe/PS1 $\triangle \mathrm{E} 9$ mice lacking mGluR5, when compared with wild-type mGluR5 knockout tissue, suggesting that mGluR1 may compensate to some extent for the loss of mGluR5 expression in the APPswe/PS1 $\triangle \mathrm{E} 9$ mice (Figure $3 \mathrm{C}$ ). This might be the consequence of compensatory mGluR1 expression in the APPswe/PS1 $1 \mathrm{E} 9$ mice [33].

\section{FMRP expression is increased in APPswe/PS1 $\triangle \mathrm{E} 9$ mice}

The activity and expression of FMRP, a RNA binding protein involved in the regulation of APP translation and processing, is modulated by mGluR5 [23,24]. Thus, it is possible that mGluR5-activated cell signaling pathways, acting independent of agonist-mediated $\mathrm{G}$ protein signaling pathways, might bias mGluR5 signaling, as a consequence of increased cell surface mGluR5 expression in APPswe/PS1 $\triangle \mathrm{E} 9$ mice, towards alternative signal transduction pathways. Specifically, mGluR5 activation not only modulates FMRP expression, but regulates FMRP activity via the activation of mTOR [34]. Therefore, we examined whether p-mTOR ( $\mathrm{p}$-2481) phosphorylation was increased in cortical brain tissue derived from wild-type and APPswe/PS1 $\triangle \mathrm{E} 9$ mice that either express or lack mGluR5 expression at 12 months of age. We found an increase in p-mTOR staining in cortical sections derived from APPswe/PS1 $\triangle \mathrm{E} 9$ mice that express mGluR5 when compared to all other genotypes (Figure 5A and C) with no significant alterations in total mTOR staining observed between phenotypes (Figure 5B and D). This corresponded to an $82 \pm 17 \%$ increase in in situ mTOR phosphorylation in cortical tissue slices from APPswe/PS1 $\triangle$ E9 mice at 12 months of age, as compared with wild-type mice. In addition, we examined 


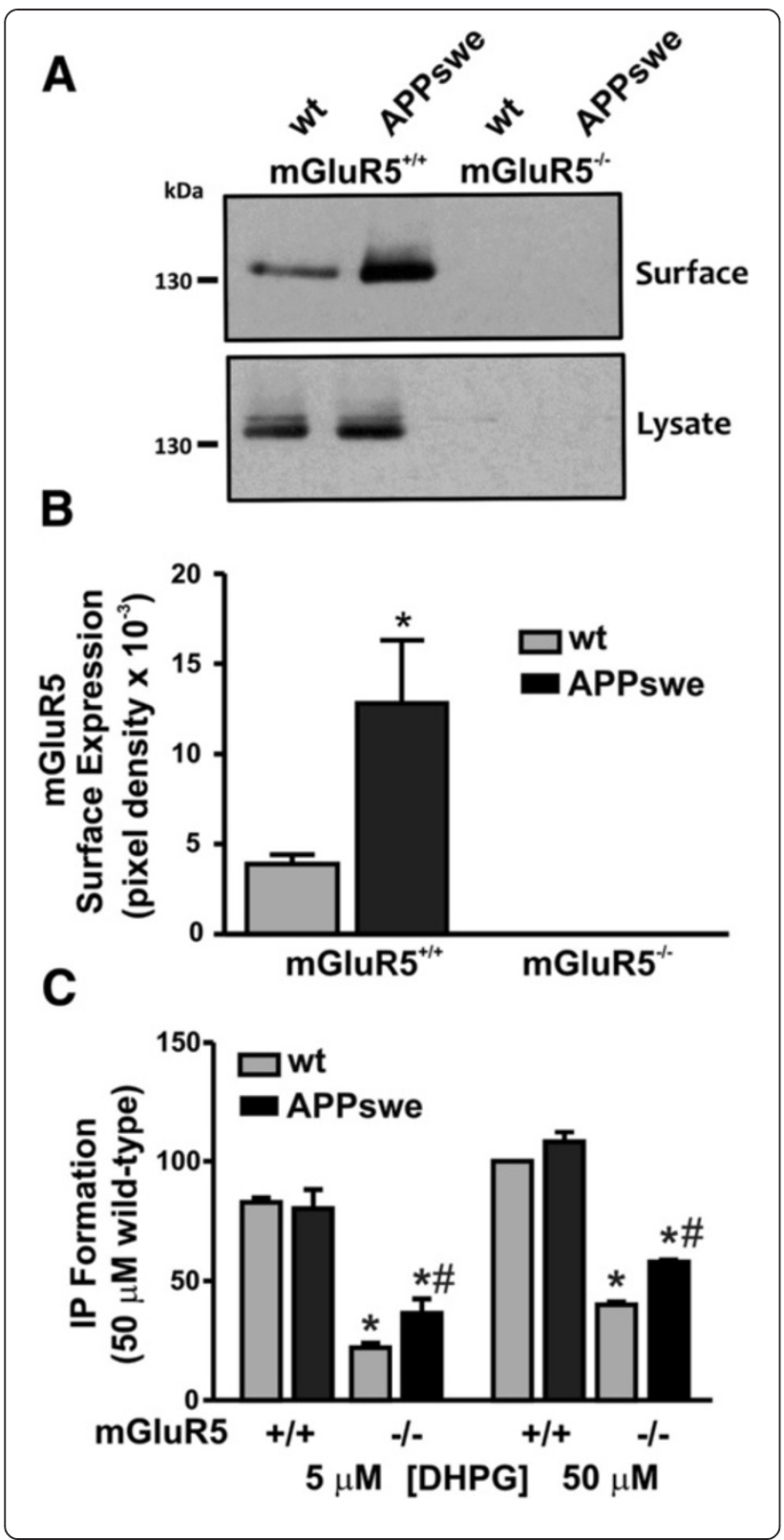

Figure 4 Increased mGluR5 cell surface expression does not alter InsP signaling in 12 month old APPswe/PS1 $\Delta$ E9 mice. (A) Shown is a representative immunoblot showing increased cell surface expression, but not total cellular expression, of mGluR5 in brain lysates derived from 12 month wild-type (wt) versus APPswe/PS1 1 E9 (APPswe) mice. Loss of mGluR5 expression following mGluR5 knockout is also shown for both mouse lines. (B) Graph shows the quantification of the relative cell surface expression of mGluR5 in wt versus APPswe mice at 12 months of age. Data represents the mean \pm SEM of four independent experiments. The ${ }^{*}$ indicates statistically significant $(P<0.05)$ differences between in APPswe mice, as compared to wt mice $(P<0.05)$. Shown in $(\mathbf{C})$ is mGluR1/5-stimulated InsP formation in response to either $5 \mu \mathrm{M}$ or $50 \mu \mathrm{M}$ DHPG for 15 min at $37^{\circ} \mathrm{C}$ in cortical prisms derived from either wt or APPswe mice, that either express mGluR5 (+/+) or do not express mGluR5 (-/-). The data represents the means \pm SEM of four independent experiments, and is expressed as percentage of the maximum response to $50 \mu \mathrm{M}$ DHPG-stimulated InsP formation in wild type slices. The * indicates statistically significant $(P<0.05)$ differences in InsP formation following treatment of tissue with either 5 or $50 \mu \mathrm{m}$ DHPG concentrations between cortical prisms derived from wt and APPswe mice and cortical prisms derived from wt and APPswe/PS1 $\triangle$ E9 mice that do not express mGluR5. " Indicates statistically significant $(P<0.05)$ differences in InsP formation following treatment of tissue with either 5 and $50 \mu \mathrm{m}$ DHPG concentrations between cortical prisms derived from wt and APPswe that do not express mGluR5.

whether mTOR (p-2481) phosphorylation was increased in brain lysates derived from APPswe/PS1 $\triangle \mathrm{E} 9$ mice at 12 months of age and found that mTOR phosphorylation was significantly increased by $22 \pm 0.8 \%$, as compared with wild-type mice (Figure $5 \mathrm{E}$ and $\mathrm{F}$ ).

Because both mGluR5 and mTOR activation influence FMRP expression and activity, we tested whether FMRP expression was altered in APPswe/PS1 $\triangle \mathrm{E} 9$ mice as compared to wild-type mice. We found that FMRP expression was increased by $2.6 \pm 0.6$ fold in APPswe/PS1 $\Delta \mathrm{E} 9$ mice at 12 months of age, as compared to wild-type mice (Figure 6A and B). Genetic deletion of mGluR5 significantly reduced FMRP expression APPswe/PS1 $\triangle \mathrm{E} 9$ mice (Figure 6A and $\mathrm{B}$ ). These observations suggest that mGluR 5 activation by $A \beta$ oligomers promotes a positive feedback loop promoting APP cleavage of AD toward the amyloidogenic pathway in APPswe/PS1 $\triangle \mathrm{E} 9$ mice.

\section{Discussion}

The neurodegeneration characteristic of $\mathrm{AD}$ is associated with $A \beta$ oligomers, which bind to neuronal synapses to both alter synaptic signaling and promote synaptic loss [35-37]. We show here, that mGluR5 signaling in double transgenic APPswe/PS1 $\triangle \mathrm{E} 9$ mice not only contributes to impaired spatial learning, but also increases the formation of $A \beta$ oligomers and $\beta$-amyloid plaques which are the pathophysiological hallmarks of $\mathrm{AD}$. In addition, spatial learning deficits observed in double transgenic APPswe/PS1 $\triangle \mathrm{E} 9$ mice are ameliorated by the genetic deletion of mGluR5, which is consistent with the 

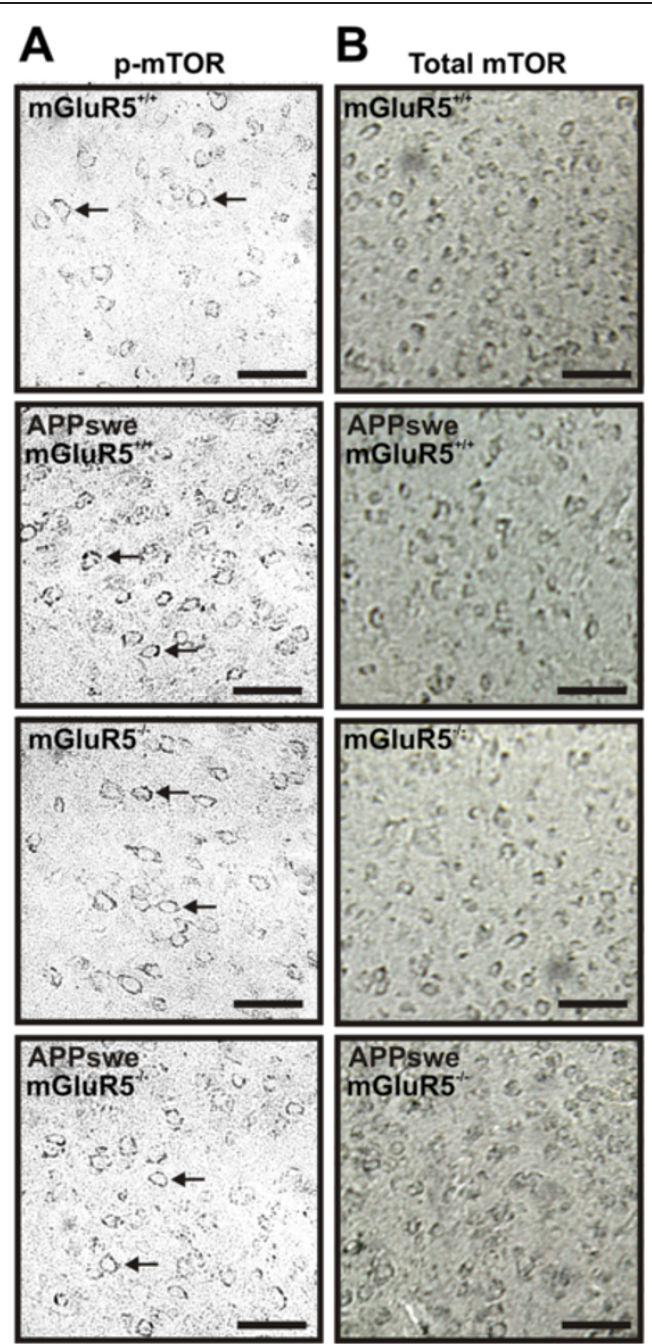

C
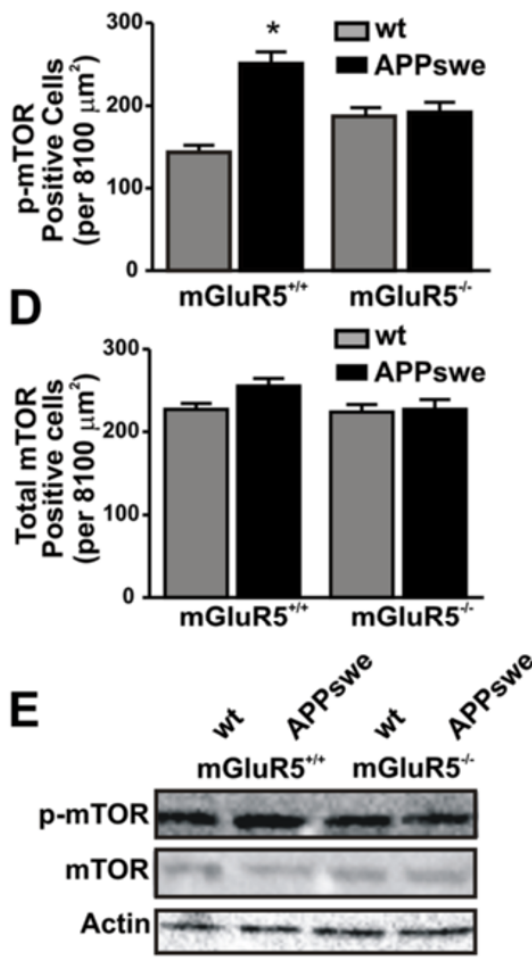

$F$

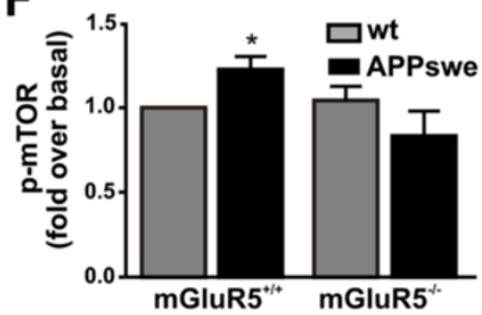

Figure 5 p-mTOR activation in APPswe/PS1 1 E9 mice. Shown is immunohistochemical staining (A) for p-mTOR (pSer2481) staining in representative fields of coronal tissue from wild type (wt), APPswe/PS1 $\mathrm{EE9}$ (APPswe), mGluR5-/- and APPswe/mGluR5-/- mice at 12 months of age (B) and mTOR (pSer2481) staining in representative fields of coronal tissue from wt, APPswe, $\mathrm{mGluR5}^{-/-}$, and APPswe/mGluR5-/- mice at 12 months of age. Scale bar $=100 \mu \mathrm{m}$. (C) The graph shows the number of $\mathrm{p}$-mTOR positive cells counted $8100 \mu \mathrm{m}^{2}$ regions of interests in the cortex of 12 month old from wt, APPswe, $\mathrm{mGluR5}^{-1-}$, and APPswe/mGluR5-/- mice. Data represents the mean \pm SEM of four independent experiments. The * indicates statistically significant $(p<0.05)$ differences between wt and APPswe mice. (D) The graph shows the number of total mTOR positive cells counted $8100 \mu \mathrm{m}^{2}$ regions of interests in the cortex of 12 month old wt, APPswe, mGluR5-/-, and APPswe/mGluR5-/-. Data represents the mean \pm SEM of four independent experiments. Shown in (E) is a representative immunoblot for p-mTOR (pSer2481), total mTOR and actin in lysates derived from cortical brain section from wt and APPswe mice that either express mGluR5 (+/+) or do not express mGluR5 $(-/-)$. (F) Shown in the graph is the analysis of the mean \pm SD for four independent experiments for mTOR phosphorylation in wt and APPswe mouse cellular lysates that either express mGluR5 or do not express mGluR5. The * indicates statistically significant $(P<0.05)$ differences between mTOR phosphorylations in APPswe as compared to wt mice.

recent report that pharmacological blockade of mGluR5 with the mGluR5-specific antagonist MTEP improved behavioural deficits in APPswe/PS1 $\triangle \mathrm{E} 9$ mice [17]. However, we unexpectedly found that mGluR5 signaling may also contribute to the etiology of $\mathrm{AD}$ pathology by promoting the formation of $A \beta$ oligomers in APPswe/ PS1 $\triangle \mathrm{E} 9$ mice, which are considered to be important mediators of neurotoxic signaling at glutamatergic synapses. It is also now recognized that mGluR5 functions as a receptor for both $\mathrm{A} \beta$ oligomers [17-19], and $\operatorname{PrP}^{\mathrm{c}}$ to mediate $A \beta$ oligomer-dependent release of $\mathrm{Ca}^{2+}$ from intracellular stores, an event which may be neurotoxic [17]. A $\beta$ oligomers also mediate clustering of mGluR 5 at synapses, the consequence of which may contribute to the functional impairment of synaptic activity [18]. Our data suggest that $A \beta$ oligomer interactions with mGluR5 may also function to accelerate $A \beta$ production via the mGluR5and FMRP-dependent activation of the amyloidogenic 


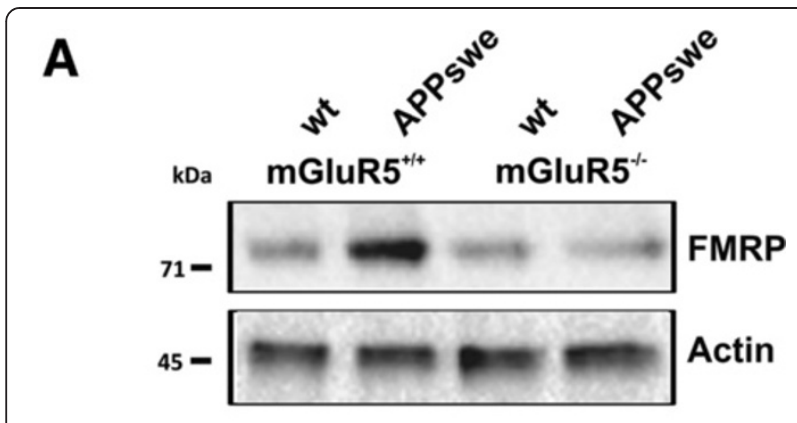

B

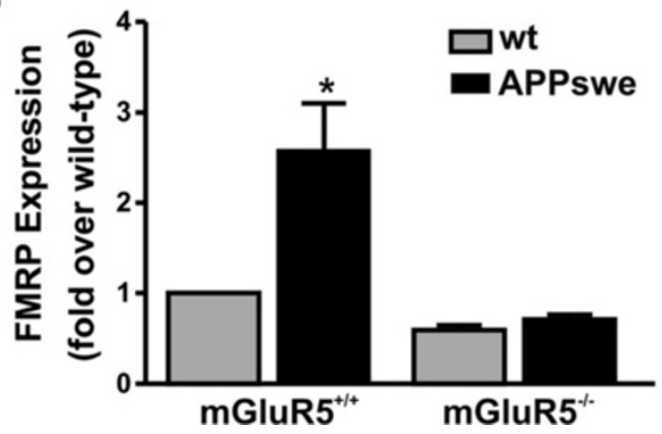

Figure 6 Increased FMRP protein expression in APPswe/PS1 1 E9 mice. (A) Shown is a representative immunoblot for FMRP expression in wild-type (wt) and APPswe/PS1 $\triangle$ E9 (APPswe) mice on either mGluR5+/+or mGluR5-/- genetic backgrounds. The data shown in (B) represent the mean \pm SD of four independent experiments demonstrating increase FMRP protein expression in APPswe mice that is lost following the genetic deletion of mGluR5. The * indicates a statistically (P 0.05) significant differences in FMRP expression between APPswe/PS1 $\triangle E 9$ mice and wild-type mice.

pathway. Thus, it appears that in the double transgenic APPswe/PS1 $\triangle \mathrm{E} 9$ mouse model of $\mathrm{AD}, \mathrm{A} \beta$ oligomers initiate a neurodegenerative positive feedback loop that increases mGluR5 activity leading to an increase in $A \beta$ oligomer formation that culminates in AD-like pathology and impaired spatial learning. The genetic deletion of mGluR5 in APPswe/PS1 $\triangle \mathrm{E} 9$ mice effectively severs this feedback loop, reducing $A \beta$ oligomer and plaque formation resulting in improved cognitive performance in APPswe/PS1 $\triangle \mathrm{E} 9$ mice.

We found that there was no change in swim speed the mouse groups tested suggesting that altered locomotion or anxiety did not account for changes in MWM performance, in the data presented to illustrate learning we showed both path length and escape latency. While an expedient escape latency could be attributed to hyperactivity, the fact that there was no difference in swim speed, and no significant difference in path length, this indicates that the mGluR5 knockout mice learn the task, as well as the wild type animals. We also found no changes in anxiety behaviour in the elevated plus maze. Our results were completely consistent with recent data showing mGluR5 antagonism improved APPswe/PS1 $\triangle \mathrm{E} 9$ mouse behaviour in MWM [17]. The previously mGluR5 knockout deficit in the MWM reported by Lu et al. [38] was in mice of undocumented age and did not involve the comparison of aged mice.

The activation of mGluR5 triggers the mRNA binding protein FMRP to release APP repression, promoting its translation $[20,23,24]$. In fragile $\mathrm{X}$ syndrome, this interaction leads to increased cleavage of APP [19,22], suggesting that similar processes may be occurring in AD brain. APP cleavage occurs via a non-amyloidogenic pathway and an amyloidogenic pathway, which is considered to function as an "overflow" pathway activated as a consequence of excessive APP production resulting in increased APP cleavage and the formation of toxic A $\beta$ oligomers $[3,39]$. Thus, $A \beta$ mediated activation of mGluR5 may result in both increased FMRP expression and APP processing. We propose that the observed increase in FMRP protein expression in APPswe/PS1 $\triangle \mathrm{E} 9$ mice represents a compensatory mechanism that is engaged to potentially reduce ectopic/transgenic translational control of APP translation. However, since mTOR activity is also increased in APPswe/PS1 $\triangle \mathrm{E} 9$ mice increased FMRP expression levels may be ineffective in reducing APP translation. There is evidence that $G$ protein-coupled receptors regulate $\gamma$-secretase activity in a $\beta$-arrestin-dependent manner to alter $A \beta$ production [40]. However, the link between mGluR5 signaling and $\beta$-arrestin activation is controversial [41]. As a consequence, $\mathrm{A} \beta$ oligomer-stimulated mGluR5 activity may function to promote the cleavage of APP via the amyloidogenic pathway.

The degeneration of glutamatergic synapses is associated with disrupted neuronal signaling and synaptic loss has traditionally been associated with alterations in ionotropic NMDA and AMPA receptor signaling [3,42-44]. However, the pharmacological blockade of the NMDAR has not met with success for the treatment of neurodegenerative disease [38]. The recent identification of mGluR5 as a potential disease modifier in $\mathrm{AD}$ provides a potential for novel mGluR5 antagonist-based pharmacological interventions for the treatment of $\mathrm{AD}$. mGluR5 blockade was effective in improving spatial learning in APPswe/PS1 $\triangle \mathrm{E} 9$ mice and we reported that mutant huntingtin protein aggregates are significantly reduced in a mutant Huntingtin knock-in model that lacks mGluR5 expression [12]. Taken together these observations suggest a generalized potential for mGluR5 antagonists in the treatment of neurodegenerative disease.

In summary, we show that mGluR5, which functions as a membrane bound receptor scaffolds for both PrPc and $A \beta$ oligomers [17-19], functions to transduce $A \beta$ oligomer-mediated signals as alterations in intracellular $\mathrm{Ca}^{2+}$ signaling, as well as FMRP/A $\beta$ mediated pathological signaling in the APPswe/PS1 $\triangle \mathrm{E} 9$ mouse model of $\mathrm{AD}$. Although these studies provide additional evidence 
establishing mGluR5 as a potentially effective drug target to antagonize AD progression, additional pharmacological studies will be required in non-human primates to validate the utility of mGluR5 antagonists for the treatment of AD patients.

\section{Materials and methods Materials}

Sulfo-NHS-SS-biotin and Neutravidin were purchased from Thermo Scientific (Waltham, MA, USA. Mouse antiFMRP antibody was purchased from Abcam (Cambridge, UK). DHPG was purchased from Tocris Bioscience (Bristol, UK). Myo- $\left[{ }^{3} \mathrm{H}\right]$-inositol was purchased from Perkin Elmer (Waltham, MA, USA). Dowex I-X8 resin, rabbit anti APP antibody, rabbit anti-phospho mTOR (pSer2481) antibody and rabbit anti-mTOR antibody were purchased from Sigma-Aldrich (St. Louis, MO, USA).Goat anti-rabbit secondary antibody was purchased from BioRad (Hercules, CA, USA). Aggregated A $\beta$ human ELISA kit and rabbit $A \beta$ peptide antibody were purchased from Invitrogen (Carlsbad, CA, USA). Rabbit anti-mGluR5 was purchased from Millipore (Billerica, MA, USA). Finally Vector Elite $\mathrm{ABC}$ kit rabbit and mouse, and Vector SG substrate was purchased from Vector laboratories. All other biochemical reagents were purchased from Sigma-Aldrich (St. Louis, MO, USA).

\section{Mouse model}

STOCK B6C3-Tg (APPswe/PSEN1 $\triangle E$ 9)85Dbo/J mice that carry the human APP with Swedish mutation and the DeltaE9 mutation of the human presenilin 1 gene and mGluR5 knockout mice B6;129-Grm $5^{\mathrm{tm} 1 \text { Rod }} / \mathrm{J}\left(\mathrm{mGluR5^{-/- }}\right)$ were purchased from Jackson Laboratory (Bar Harbor, ME) $[38,45]$. APPswe/PS1 $\Delta \mathrm{E} 9 / \mathrm{mGluR}^{-/-}$mice were generated by crossing APPswe/PS1 $\Delta \mathrm{E} 9$ mice with a $\mathrm{C} 57 / \mathrm{Bl} 6$ background, with mGluR5-/- C57/Bl6 females. Offspring were tail snipped and genotyped using PCR with primers specific for the APP sequence and primers specific for mGluR5. The following genotypes were generated and used for experiments APPswe/PS1 $\triangle \mathrm{E} 9 /$ mGluR5 ${ }^{-/-}$, APPswe/PS1 $\Delta$ E9/mGluR5 ${ }^{+/+}$, APPswe/PS1 $\Delta$ E9 ${ }^{-/-} / \mathrm{mGluR}^{-/-}$and wild type littermate controls. Animals were housed in an animal care facility in cages of 2 or more animals, and were maintained on a 12 hour light/12 hour dark cycle at $24^{\circ} \mathrm{C}$. Mice received food and water ad libitum. Mice were aged to 9 and 12 months before use in a battery of behavioural and biochemical experiments. All animal experiments were conducted in accordance with the University of Western Ontario animal care committee.

\section{Morris water maze}

Any Maze software connected to a video camera was used to track the activity of animals within the maze. The maze was a white opaque plastic pool $(120 \mathrm{~cm}$ in diameter), filled with water and maintained at $25^{\circ} \mathrm{C}$ to prevent hypothermia. A clear escape platform $(10 \mathrm{~cm}$ diameter) was placed $25 \mathrm{~cm}$ from the perimeter, hidden $1 \mathrm{~cm}$ beneath the surface of the water. Visual cues were placed on the walls in the room with the maze. Acquisition phase (day 1-4): Mice were trained over 4 consecutive days, with 4 trials per day with 15 min intervals between trials. Mice were randomly started from 4 equally spaced points around the pool, across each of the 4 daily trials. Animals were given $90 \mathrm{~s}$ to find the escape platform, if they failed to do so they were guided to the platform where they remained for $30 \mathrm{~s}$, before being returned to their home cage. Swim speed and escape latency were recorded and statistical analysis performed using Graph Pad Prism. Probe trial (day 5): the probe trial is performed to assess spatial memory. This is a singular $60 \mathrm{~s}$ trial, in which the platform is removed and mice are allowed to swim freely in the pool. Time spent in the target quadrant was recorded and statistical analysis performed using Graph Pad Prism software.

\section{Open field}

VersaMax animal activity monitors (AccuScan Instruments Inc, Columbus, OH, USA) were used to measure locomotor activity. Experiments were performed during the light cycle of the mice. Mice were allowed to explore open field boxes $(20 \times 20 \mathrm{~cm}$ Plexi-glass boxes $)$ for $120 \mathrm{~min}$ during which time movement was measured at 5 min intervals using beam breaks converted to $\mathrm{cm}$. Measurements of total distance travelled, center time and number of rearings were calculated and statistical analysis performed using Graph Pad Prism software.

\section{Elevated plus maze}

Mice were individually placed in one of the enclosed arms of a plus-maze and the behavior of the animals was recorded over a $5 \mathrm{~min}$ period by a ceiling-mounted video camera. The amount of time spent in each of the arms, the number of arm entries (an arm entry was defined as all four of the paws being placed in an arm of the plusmaze). The elevated plus-maze had two arms enclosed by $21 \mathrm{~cm}$ high walls; whereas the remaining two arms were open (arms were $24.8 \mathrm{~cm}$ long $\times 7.7 \mathrm{~cm}$ wide). The maze was situated in a dimly lit room, such that the closed arms were darkened, whereas open arms were somewhat illuminated. All behavioural experiments were blinded.

\section{Determination of $\beta$ amyloid oligomer concentration by sandwich ELISA}

Brains were dissected into right and left hemisphere, with one hemisphere used to analyse oligomeric $A \beta$. Quantification of $A \beta$ oligomers, in 12 month old fresh mouse brains, was performed using a sandwich ELISA kit (KHB3491, Invitrogen) according to manufacturer's instructions. 
Briefly, wild-type, APPswe/PS1 $\Delta \mathrm{E} 9 / \mathrm{mGluR}^{-/-}$, APPswe/ PS1 $\Delta$ E $9 / \mathrm{mGluR}^{+/+}$, APPswe/PS1 $\Delta \mathrm{E}^{-/-} / \mathrm{mGluR}^{-/-}$mouse brains were homogenized in Tris Buffered Saline (25 mM Tris- $\mathrm{HCl}, \mathrm{pH} 7.4 ; 150 \mathrm{mM} \mathrm{NaCl}$ ) supplemented with protease inhibitor cocktail ( $1 \mathrm{mM}$ AEBSF, and10 $\mu \mathrm{g} / \mathrm{ml}$ aprotinin of both leupeptin). Brain homogenates were centrifuged at $100,000 \times g$ at $4^{\circ} \mathrm{C}$ for 1 hour. The supernatant was then diluted 1:10 before carrying out the ELISA, which was performed in triplicate, measuring only $A \beta$ oligomers, as detailed in the manufacturer's protocol. Protein was quantified using the Bradford protein assay (BioRad). The final $A \beta$ values were determined following normalization to total protein levels.

\section{$\beta$ amyloid immunohistochemistry}

Brains were dissected into left and right hemisphere, with one hemisphere used for histology. Brains were coronally sectioned to include both the cortex and hippocampus. Immunohistochemistry was performed on $40 \mu \mathrm{m}$ free floating sections using a peroxidase based immunostaining protocol. In brief, endogenous peroxidase activity was quenched using $0.1 \%$ hydrogen peroxide, after which the membranes were permeabilized using 1\% triton X100 in TBS. Non-specific binding was blocked using 1.5\% normal goat serum, followed by incubation in primary antibody for $A \beta$ (1:200, rabbit polyclonal, Invitrogen) overnight at $4^{\circ} \mathrm{C}$. Sections were washed in $1 \times$ TBS, and then incubated in secondary antibody (biotinylated goat anti-rabbit, 1:400, Vector Elite ABC kit rabbit, Vector Laboratories) for $90 \mathrm{~min}$ at $4^{\circ} \mathrm{C}$. Finally sections were incubated in an avidin biotin enzyme reagent (Vector Elite ABC kit rabbit, Vector Laboratories). Immunostaining was visualised using a chromogen (Vector SG substrate, Vector Laboratories). Sections were mounted on slides and visualized using a Zeiss LSM-510 META multiphoton laser scanning microscope with a Zeiss $10 \times$ lens, representative $900 \mu \mathrm{m} \times$ $900 \mu \mathrm{m}$ areas of cortex (4 regions of interest) and hippocampus (2 regions of interest) were imaged for analysis. The number of $A \beta$ positive puncta per image was counted using the cell counter tool in Image J (NIH, USA).

\section{Cell surface biotinylation}

Cell surface biotinylation was performed as previously described $^{11}$. $350 \mu \mathrm{m}$ coronal brain slices from wild-type, APPswe/PS1 $\Delta$ E9/mGluR5 ${ }^{-/-}$, APPswe/PS1 $\Delta \mathrm{E} 9 / \mathrm{mGluR}^{+/+}$, APPswe $/ \mathrm{PS} 1 \Delta \mathrm{E} 9^{-/-} / \mathrm{mGluR}^{-/-}$mice were prepared using a vibratome system (Leica). Slices were recovered in KREBS buffer (127 mM NaCl, $2 \mathrm{mM} \mathrm{KCl,} 10 \mathrm{mM}$ glucose, $1.2 \mathrm{mM}$ $\mathrm{KH}_{2} \mathrm{PO}_{4}, 26 \mathrm{mM} \mathrm{NaH} \mathrm{CO}_{3}, 1 \mathrm{mM} \mathrm{MgSO}$, $1 \mathrm{mM} \mathrm{CaCl}$, $\mathrm{pH}$ 7.4) continuously gassed with $95 \% \mathrm{O}_{2} / 5 \% \mathrm{CO}_{2}$ for $30 \mathrm{~min}$ at $37^{\circ} \mathrm{C}$. Slices were transferred to tubes and biotinylated for $1 \mathrm{hr}$ in $1.5 \mathrm{mg} / \mathrm{ml}$ sulfo-NHS-SS-biotin (Thermo Scientific) for $1 \mathrm{~h}$ on ice. Slices were washed and biotinylation quenched with $100 \mu \mathrm{M}$ glycine in HBSS for $30 \mathrm{~min}$ on ice.
Following washes in HBSS, tissue was lysed in RIPA buffer (0.15 M NaCl, 0.05 M Tris-HCl, pH 7.2, 0.05 M EDTA, $1 \%$ Nonidet P40, 1\% Triton X-100, 0.5\% sodium deoxycholate, $0.1 \%$ SDS) containing protease inhibitors (1 mM AEBSF and $10 \mu \mathrm{g} / \mathrm{ml}$ of both leupeptin and aprotinin), lysates were then polytroned until homogenous. Biotinylated proteins were then precipitated on NeutrAvidin beads using equivalent amounts of cellular protein for each sample. Biotinylated proteins were subjected to SDS-PAGE and immunoblotted with Rabbit polyclonal mGluR5 antibody (1:1000, dilution), as described below.

\section{Immunoblotting}

Acute brain slices prepared, as described above, and recovered for $90 \mathrm{~min}$ at $37^{\circ} \mathrm{C}$ in KREBS continuously gassed with $95 \% \mathrm{O}_{2} / 5 \% \mathrm{CO}_{2}$. Slices were then transferred to tubes, gassed with $95 \% \mathrm{O}_{2} / 5 \% \mathrm{CO}_{2}$ before being capped tightly and left to further recover at $37^{\circ} \mathrm{C}$ for $30 \mathrm{~min}$. Slices were flash frozen with $95 \%$ ethanol in a bath of dry ice and lysed in RIPA buffer. $100 \mu \mathrm{g}$ of total cellular protein for each sample were subjected to SDS-PAGE, followed by electroblotting onto nitrocellulose membranes. Membranes were blocked with $10 \%$ milk in wash buffer $(150 \mathrm{mM} \mathrm{NaCl}$, $10 \mathrm{mM}$ Tris- $\mathrm{HCl}, \mathrm{pH} 7.0$, and $0.05 \%$ Tween 20) for $1 \mathrm{~h}$ and then incubated with rabbit anti-APP (1:4000), rabbit anti-p-mTOR (pSer2481, 1:1000), rabbit anti-mTOR $(1: 1000)$, mouse anti-FMRP $(1: 1000)$ or rabbit anti-actin (1:10000) antibodies in wash buffer containing $3 \%$ milk overnight. Membranes were rinsed three times with wash buffer and then incubated with secondary horseradish peroxidase-conjugated goat anti-rabbit or anti-mouse IgG diluted 1:10000 in wash buffer containing 3\% skim milk for $1 \mathrm{~h}$.

\section{Inositol phosphate formation assay}

$\left[{ }^{3} \mathrm{H}\right]$ Inositol phosphate formation in cortical slices was performed, as previously described ${ }^{11}$. Dissected cortices from age-matched wild-type, APPswe/PS1 $\triangle \mathrm{E} 9 / \mathrm{mGluR}^{-/-}$, APPswe/PS1 $\Delta \mathrm{E} 9 / \mathrm{mGluR}^{+/+}$, APPswe/PS1 $\Delta \mathrm{E}^{-/-} / \mathrm{mGluR}^{-/-}$ mouse brains were cross-chopped using a Mcllwain tissue chopper. The cortical prisms were recovered by incubation in KREBS buffer after being gassed with $95 \% \mathrm{O}_{2} / 5 \% \mathrm{CO}_{2}$ in a shaking water bath at $37^{\circ} \mathrm{C}$ for $30 \mathrm{~min} .40 \mu \mathrm{l}$ of gravitypacked prisms were transferred in duplicate to tubes, gassed, and incubated with $1 \mu \mathrm{Ci} / \mathrm{ml}$ myo- $\left[{ }^{3} \mathrm{H}\right]$ inositol in a shaking bath at $37^{\circ} \mathrm{C}$ for $90 \mathrm{~min}$. The prisms were gassed again and incubated in a shaking water bath at $37^{\circ} \mathrm{C}$ for $15 \mathrm{~min}$ in $10 \mathrm{mM} \mathrm{LiCl}$ followed by stimulation with $5 \mu \mathrm{M}$ or $50 \mu \mathrm{M}$ DHPG for $20 \mathrm{~min}$. The reaction was stopped by adding $900 \mu \mathrm{l}$ of a 2:1 mix of chloroform: methanol incubated for $15 \mathrm{~min}$ at room temperature, followed by adding $300 \mu \mathrm{l}$ of chloroform. The total $\left[{ }^{3} \mathrm{H}\right]$ inositol incorporated into slices was determined by counting the radioactivity present in the hydrophobic 
layer. $700 \mu \mathrm{l}$ of aqueous layer was added to Dowex 1-X8 (formate form) 200-400 mesh anion exchange resin in columns. Columns were washed three times with water followed by 2 washes with $60 \mathrm{mM}$ ammonium formate. Samples were eluted with $200 \mathrm{mM}$ ammonium formate and $0.1 \mathrm{M}$ formic acid into scintillation vials containing scintillation fluid. $\left[{ }^{3} \mathrm{H}\right]$ Inositol phosphate formation was determined by liquid scintillation using a Beckman LS 6500 scintillation system.

\section{p-TOR and mTOR immunohistochemistry}

Brains were coronally sectioned to include both the cortex and hippocampus. Immunohistochemistry was performed on $40 \mu \mathrm{m}$ free floating sections using a peroxidase based immunostaining protocol. In brief; endogenous peroxidase activity was quenched using $0.1 \%$ hydrogen peroxide, after which the membranes were permeabilized using $1 \%$ triton X100 in TBS. Non-specific binding was blocked using $1.5 \%$ normal goat serum, followed by incubation in primary antibody for p-mTOR (1:200 diltion, rabbit polyclonal pSer2481 antibody) and mTOR (1:200, rabbit polyclonal antibody) overnight at $4^{\circ} \mathrm{C}$. Sections were washed in 1xTBS, and then incubated in secondary antibody (biotinylated goat anti-rabbit, 1:400, Vector Elite $\mathrm{ABC}$ kit rabbit, Vector Laboratories) for $90 \mathrm{~min}$ at $4{ }^{\circ} \mathrm{C}$. Finally sections were incubated in an avidin biotin enzyme reagent (Vector Elite ABC kit rabbit, Vector Laboratories). Immunostaining was visualised using a chromogen (Vector SG substrate, Vector Laboratories). Sections were mounted on slides and visualized using a Zeiss LSM-510 META multiphoton laser scanning microscope with a Zeiss $10 \times$ lens, representative $900 \mu \mathrm{m} \times 900 \mu \mathrm{m}$ areas of cortex (4 regions of interest) and hippocampus ( 2 regions of interest) were imaged for analysis. The number of p-mTOR and mTOR positive cells per image was counted using the cell counter tool in Image J (NIH, USA).

\section{Data analysis}

Means \pm SEM are shown for the number of independent experiments indicated in Figure Legends. GraphPad Prism software was used to analyze data for statistical significance and for curve fitting. Statistical significance was determined by analysis of variance (ANOVA) followed by post-hoc testing.

\section{Additional file}

Additional file 1: Figure S1. Time spent in each of the quadrants of the Morris Water Maze for each of the mouse genotypes tested and 12 months of age.

\section{Abbreviations}

AD: Alzheimer's disease; APP: Amyloid precursor protein; $A \beta$ : $\beta$-amyloid; PrPC: Cellular prion protein; FMRP: Fragile X mental retardation protein; InsP: Inositol phosphate; mGluR5: Metabotropic glutamate receptor 5.

\section{Competing interests}

The authors declare that they have no competing interests.

\section{Authors' contribution}

AH: performed the behavioural experiments, beta amyloid analysis, immunohistochemistry, and biochemistry, data analysis and writing of the manuscript. JLE: performed cell surface biotinylation and IP experiments. RAD: assisted with a number of the behaviour experiments. SPC: contributed to the writing of the manuscript. SSGF: Principle investigator, contributed to the experimental design, data analysis and writing of the manuscript. All authors read and approved the final manuscript.

\section{Acknowledgements}

S. S. G. F. holds a Tier I Canada Research Chair in Molecular Neurobiology and is a Career Investigator of the Heart and Stroke Foundation of Ontario. S. P. C. holds a Tier II CRC in Neurodegeneration and Repair. We thank Dr. Vania Prado for her technical expertise and Dr. Hymie Anisman for statistical advice.

\section{Funding}

This work was supported by the Canadian Institutes of Health Research [grant number MOP-119437] to S. S. G. F.

Received: 9 May 2014 Accepted: 23 May 2014

Published: 29 May 2014

\section{References}

1. Dubois B, Feldman HH, Jacova C, Hampel H, Molinuevo JL, Blennow K, DeKosky ST, Gauthier S, Selkoe D, Bateman R, Cappa S, Crutch S, Engelborghs S, Frisoni GB, Fox NC, Galasko D, Habert MO, Jicha GA, Nordberg A, Pasquier F, Rabinovici G, Robert P, Rowe C, Salloway S, Sarazin M, Epelbaum S, de Souza LC, Vellas B, Visser PJ, Schneider L, Stern Y, Scheltens P, Cummings JL: Advancing research diagnostic criteria for Alzheimer's disease: the IWG-2 criteria. Lancet Neurol 2014, 13:614-629.

2. Hebert LE, Scherr PA, Bienias JL, Bennett DA, Evans D: Alzheimer disease in the U.S. population: prevalence estimates using the 2000 census. Arch Neurol 2003, 60:1119-1122

3. Kamenetz F, Tomita T, Hseih H, Seabrook G, Borchelt D, Iwatsubo T, Sisodia S, Malinow R, Point W: APP processing and synaptic function. Neuron 2003, 37:925-937.

4. Selkoe DJ: Toward a comprehensive theory for Alzheimer's disease. Hypothesis: Alzheimer's disease is caused by the cerebral accumulation and cytotoxicity of amyloid $\beta$-protein. Ann NY Acad Sci 2006, 924:17-25.

5. McGowan E, Pickford F, Kim J, Onstead L, Eriksen J, Yu C, Skipper L, Murphy MP, Beard J, Das P, Jansen K, Delucia M, Lin WL, Dolios G, Wang R, Eckman CB, Dickson DW, Hutton M, Hardy J, Golde T: Abeta42 is essential for parenchymal and vascular amyloid deposition in mice. Neuron 2006, 47:191-199.

6. Gong Y, Chang L, Viola KL, Lacor PN, Lambert MP, Finch CE, Krafft GA, Klein WL: Alzheimer's disease-affected brain: presence of oligomeric a beta ligands (ADDLs) suggests a molecular basis for reversible memory loss. PNAS 2003, 100:10417-10422.

7. Lacor PN, Buniel MC, Chang L, Fernandez SJ, Gong Y, Viola KL, Lambert MP, Velasco PT, Bigio EH, Finch CE, Krafft G, Klein WL: Synaptic targeting by Alzheimer's-related amyloid beta oligomers. J Neurosci 2004, 24:10191-10200.

8. Dhami GK, Ferguson SSG: Metabotropic glutamate receptor desensitization. Pharmacol Ther 2006, 111:260-271.

9. Ribeiro FM, Paquet M, Cregan SP, Ferguson SSG: Group 1 metabotropic glutamate receptor signaling and its implication in neurological disease. CNS Neurol Discord Drug Targets 2010, 9:574-595.

10. Thathiah A, De Strooper B: The role of $G$ protein-coupled receptors in the pathology of Alzheimer's disease. Nat Rev Neurosci 2011, 12:73-87.

11. Ribeiro FM, Paquet M, Ferreira LT, Cregan T, Swan P, Cregan SP, Ferguson SSG: Metabotropic glutamate receptor-mediated cell signaling pathways are altered in a mouse model of Huntington's disease. J Neurosci 2010, 30:316-324.

12. Ribeiro FM, DeVries RA, Hamilton A, Guimaraes IM, Cregan SP, Pires RGW, Ferguson SSG: Metabotropic glutamate receptor 5 knockout promotes motor and biochemical alterations in a mouse model of Huntington's disease. Hum Mol Genet 2013, 23:2030-2042. 
13. Arif M, Kazim SF, Grundke-lqbal I, Garruto RM, lqbal K: Tau pathology involves protein phosphatase 2A in Parkinsonism-dementia of Guam. Proc Natl Acad Sci U S A 2014, 111:1144-1149.

14. Michalon A, Sidorov M, Ballard TM, Ozmen L, Spooren W, Wettstein JG, Jaeschke G, Bear MF, Lindemann L: Chronic pharmacological mGluR5 inhibition corrects Fragile X in mice. Neuron 2012, 74:49-56.

15. Lee RK, Wurtman RJ, Cox AJ, Nitsch RM: Amyloid precursor protein processing is stimulated by metabotropic glutamate receptors. Proc Natl Acad Sci U S A 1995, 92:8083-8087.

16. Malter JS, Ray BC, Westmark PR, Westmark CJ: Fragile $X$ syndrome and Alzheimer's disease: another story about APP and $\beta$-amyloid. Curr Alz Res 2010, 7:200-206.

17. Um JW, Kaufman AC, Kostylev M, Heiss JK, Stagi M, Takahashi H, Kerrisk ME, Vortmeyer A, Wisniewski T, Koleske AJ, Gunther EC, Nygaard HB, Strittmatter SM: Metabotropic glutamate receptor 5 is a coreceptor for Alzheimer $A \beta$ oligomer bound to cellular prion protein. Neuron 2013, 79:887-902.

18. Beraldo FH, Arantes CP, Santos TG, Machado CF, Roffe M, Hajj GN, Lee KS, Magalhães AC, Caetano FA, Mancini GL, Lopes MH, Américo TA, Magdesian MH, Ferguson SSG, Linden R, Prado MA, Martins VR: Metabotropic glutamate receptors transduce signals for neurite outgrowth after binding of the prion protein to laminin $\gamma 1$ chain. FASEB J 2011, 25:265-279.

19. Sokol DK, Mahoney B, Long JM, Ray B, Lahiri DK: Autism, Alzheimer's disease, and fragile X. APP, FMRP and mGluR5 are molecular links. Neurology 2011, 76:1344-1352.

20. Renner M, Lacor PN, Velasco PT, Xu J, Contractor A, Klein WL, Triller A: Deleterious effects of amyloid beta oligomers acting as an extracellular scaffold for mGluR5. Neuron 2010, 66:739-754.

21. Todd $P$, Mack K, Malter JS: The fragile $X$ mental retardation protein is required for type-I metabotropic glutamate receptor-dependent translation of PSD-95. Proc Natl Acad Sci U S A 2003, 98:14374-14378.

22. Bear $M$, Huber $K$, Warren S: The mGluR theory of fragile $X$ mental retardation. Trends Neurosci 2004, 27:370-377.

23. Ashley CJ, Wilkinson K, Reines D, Warren S: FMR1 protein: conserved RNP family domains and selective RNA binding. Science 1993, 262:563-566.

24. Westmark CJ, Malter JS: The regulation of AßPP expression by RNA-binding proteins. Ageing Res Rev 2012, 11:450-459.

25. Greenough W, Klintsova AY, Irwin SA, Galvez R, Bates KE, Weiler U: Synaptic regulation of protein synthesis and the fragile $X$ protein. Proc Natl Acad Sci U S A 2001, 98:7101-7106.

26. Westmark CJ, Malter JS: FMRP mediates mGluR5-dependent translation of amyloid precursor protein. PLOS Biol 2007, 5:e52.

27. Westmark CJ, Westmark PR, O'Riordan KJ, Ray BC, Hervey CM, Salamat MS, Abozeid SH, Stein KM, Stodola LA, Tranfaglia M, Burger C, Berry-Kravis EM, Malter JS: Reversal of fragile $X$ phenotypes by manipulation of $A \beta P P / A \beta$ levels in Fmr1KO mice. PLOS One 2011, 6:e26549.

28. O'Leary TP, Brown RE: Visuo-spatial learning and memory deficits on the Barnes maze in the 16-month-old APPswe/PS1dE9 mouse model of Alzheimer's disease. Behav Brain Res 2009, 201:120-127.

29. Lalonde R, Kim HD, Maxwell JA, Fukuchi K: Exploratory activity and spatial learning in 12-month-old APP(695)SWE/co + PS1/DeltaE9 mice with amyloid plaques. Neurosci Lett 2005, 390:87-92.

30. Volianskis A, Køstner R, Mølgaard M, Hass S, Jensen MS: Episodic memory deficits are not related to altered glutamatergic synaptic transmission and plasticity in the CA1 hippocampus of the APPswe/PS18E9-deleted transgenic mice model of ß-amyloidosis. Neurobiol Aging 2010, 31:1173-1187.

31. Hamilton A, Holshcer $C$ : The effect of ageing on neurogenesis and oxidative stress in the APP(swe)/PS1(deltaE9) mouse model of Alzheimer's disease. Brain Res 2012, 1449:83-93.

32. Ribeiro FM, Ferreira LT, Paquet M, Cregan T, Ding Q, Gros R, Ferguson SSG: Phosphorylation-independent regulation of metabotropic glutamate receptor 5 desensitization and internalization by $\mathrm{G}$ protein-coupled receptor kinase 2 in neurons. J Biol Chem 2009, 284:23444-23453.

33. Ostapchenko VG, Beraldo FH, Guimaraes AL, Mishra S, Guzman M, Fan J, Martins JR, Prado VF, Prado MA: Increased prion protein processing and expression of metabotropic glutamate receptor 1 in a mouse model of Alzheimer's disease. J Neurochem 2013, 127:415-427.

34. Osterweil EK, Krueger DD, Reinhold K, Bear MF: Hypersensitivity to mGluR5 and ERK1/2 leads to excessive protein synthesis in the hippocampus of a mouse model of fragile X syndrome. J Neurosci 2010, 30:15616-15627.

35. Walsh DM, Klyubin I, Fadeeva JV, Cullen WK, Anwyl R, Wolfe MS, Rowan MJ, Selkoe DJ: Naturally secreted oligomers of amyloid beta protein potently inhibit hippocampal long-term potentiation in vivo. Nature 2002, 416:535-539.

36. Ferreira ST, Klein WL: The $A \beta$ oligomer hypothesis for synapse failure and memory loss in Alzheimer's disease. Neurobiol Learn Mem 2011, 96:529-543.

37. De Felice FG, Viera MNN, Bomfim TR, Decker H, Velasco PT, Lambert MP, Viola KL, Zhao WQ, Ferreira ST, Klein WL: Protection of synapses against Alzheimer's-linked toxins: insulin signaling prevents the pathogenic binding of Abeta oligomers. Proc Natl Acad Sci U S A 2009, 106:1971-1976.

38. Lu YM, Jia Z, Janus C, Gerlai R, Wojtowicz JM, Roder JC: Mice lacking metabotropic glutamate receptor 5 show impaired learning and reduced CA1 long-term potentiation (LTP) but normal CA3 LTP. J Neurosc 1997, 17:5196-5205.

39. Ma H, Lesné S, Kotilinek L, Steidl-Nichols JV, Sherman M, Younkin L, Younkin S, Forster C, Sergeant N, Delacourte A, Vassar R, Citron M, Kofuji P, Boland LM, Ashe $\mathrm{KH}$ : Involvement of beta-site APP cleaving enzyme 1 (BACE1) in amyloid precursor protein-mediated enhancement of memory and activity-dependent synaptic plasticity. Proc Natl Acad Sci U S A 2007, 104:8167-8172.

40. Thathiah A, Horré K, Snellinx A, Vandewyer E, Huang Y, Ciesielska M, De Kloe G, Munck $S$, De Strooper $B$ : $\beta$-arrestin 2 regulates $A \beta$ generation and $\gamma$-secretase activity in Alzheimer's disease. Nat Med 2013, 19(1):43-49.

41. Ferguson SSG: Phosphorylation-independent attenuation of GPCR signaling. Trends Pharmacol Sci 2007, 28:173-179.

42. Haass C, Selkoe DJ: Soluble protein oligomers in neurodegeneration: lessons from the Alzheimer's amyloid beta-peptide. Nat Rev Mol Cell Biol 2007, 8:101-112.

43. Townsend M, Shankar GM, Mehta T, Walsh DM, Selkoe DJ: Effects of secreted oligomers of amyloid beta-protein on hippocampal synaptic plasticity: a potent role for trimers. J Physiol 2006, 572:477-492.

44. Kalia LV, Kalia SK, Salter MW: NMDA receptors in clinical neurology: excitatory times ahead. Lancet Neurol 2008, 7:742-755.

45. Jankowsky JL, Fadale DJ, Anderson J, Xu GM, Gonzales V, Jenkins NA, Copeland NG, Lee MK, Younkin LH, Wagner SL, Younkin SG, Borchelt DR: Mutant presenilins specifically elevate the levels of the 42 residue beta-amyloid peptide in vivo: evidence for augmentation of a 42-specific gamma secretase. Hum Mol Genet 2004, 13:159-170.

doi:10.1186/1756-6606-7-40

Cite this article as: Hamilton et al:: Metabotropic glutamate receptor 5 knockout reduces cognitive impairment and pathogenesis in a mouse model of Alzheimer's disease. Molecular Brain 2014 7:40.

\section{Submit your next manuscript to BioMed Central and take full advantage of:}

- Convenient online submission

- Thorough peer review

- No space constraints or color figure charges

- Immediate publication on acceptance

- Inclusion in PubMed, CAS, Scopus and Google Scholar

- Research which is freely available for redistribution 